\title{
WASTE AND THE ELDERLY
WORKING POOR IN HONG
KONG
TrangX.Ta
}

CCENES OF THE elderly working - poor breaking down cardboard, stacking it on trolleys and pushing it along densely packed streets to be sold at recycling centres are a common sight in Hong Kong. During the Lunar New Year celebrations, the cardboard accumulates in dishevelled piles in alleyways because the recycling centres are closed for the holiday; the unpaid labour contributing to the city's waste management infrastructure becomes obvious from the sheer amount of disarrayed cardboard and discarded waste that remains uncollected during this period.

Daily life for those engaged in cleaning the streets of refuse, bundling empty cardboard boxes discarded by many businesses and salvaging abandoned materials for reuse and resale in informal street markets is a visible struggle in a place where vast disparities in wealth persist. The annual Hong Kong Poverty Situation Report $2018,{ }^{1}$ published by the government in December 2019, noted that the number of elderly poor aged sixty-five and over rose to 516,600 persons, with the poverty rate remaining steady from the previous year at 44.4 percent (within the range of 43.5 percent to 45.1 percent since 2009). Among poor households in Hong Kong overall, 39.4 percent are elderly households; and among the general elderly population, 53.1 percent are women. Thus, the activity of collecting cardboard is commonly undertaken by elderly women. 
The government provides a wide range of social security services for the elderly with various eligibility requirements. Direct cash assistance includes the Comprehensive Social Security Scheme and Old Age Living Allowance, and non-cash assistance includes subsidised public housing, healthcare vouchers, discounted public transportation, district and neighbourhood elderly community centres, and residential care homes. There are also local charities that run social outreach programs and provide additional free services. Some restaurants provide free or discounted meals for the elderly poor. The report found that, among the elderly poor counted in the survey, 86.2 percent or 445,300 persons were receiving some social security benefits from the government. The Old Age Living Allowance of HK\$1,435 (AU\$250) per month is, however, popularly referred to as 'fruit money' because such a minimal amount will only purchase some fruit or snacks. The poverty line in Hong Kong is HK\$4,000 per month (AU\$695) for a one-person household and HK\$10,000 per month (AU\$1,735) for a two-person household. The elderly poor seek out charities and community centres that provide free meals and groceries to supplement their food requirements due to the inadequacy of government cash assistance to cover all their needs.

The socially marginalised and economically vulnerable have always struggled to survive in densely populated Hong Kong, with its chronic housing shortages and prohibitive cost of living. According to the Hong Kong Housing Authority, as of 2020, the current waiting time for subsidised public housing is 5.6 years for general applicants and 3.3 years for single elderly applicants. The elderly working poor must be resourceful and adaptive to make a living, and healthy enough to deal with the physical challenges of work. The creation of informal street markets where they sell secondhand, discarded and outdated goods is an example of how marginalised communities find a means to redistribute resources.

In one of Hong Kong's poorest districts, Sham Shui Po in Kowloon, regular and itinerant hawkers set up each evening to sell second-hand goods to locals in the area, most of whom are also working poor, homeless or refugees awaiting approval of their asylum claims. On the weekends, migrant workers from the Philippines 


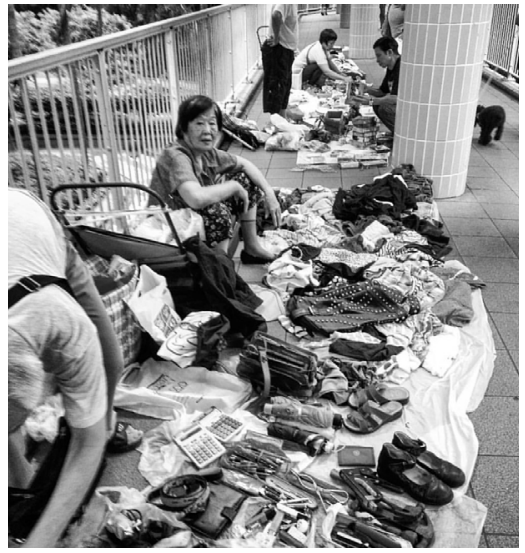

| Hong Kong's 'street stall grannies'

Source: igapp, Flickr

and Indonesia come to the area on their day off to shop for both new and used goods. Before the COVID-19 pandemic restricted international travel, African merchants who came to this district for the wholesale clothing suppliers would also be seen at the informal markets buying second-hand goods for resale back in Africa. However, hawking on the streets is not without risk and is an unreliable source of income. Hawkers can be fined by officers of the Food and Environmental Hygiene Department who regularly patrol the streets of this neighbourhood in the evenings to enforce public hygiene codes and obstruction and nuisance ordinances. In these cases, the goods are confiscated and disposed of.
Waste took on new visibility and purpose during the protests of 2019-2020. Global and local media attention focused on what became, throughout much of 2019, daily clashes between protesters and the police across Hong Kong. The dramatic and historic protests also generated an epic amount of rubbish. Accumulated debris included pieces of broken pavement, disposable facemasks, ripped gloves, empty water bottles, contorted umbrellas, shattered glass, uprooted signposts, plastic food packaging, burnt rubbish, and discharged tear-gas canisters. Protesters, meanwhile, appropriated bright orange drums used as garbage bins from the sidewalks, multicoloured neighbourhood recycling receptacles, and large green wheeled dumpsters to build blockades and barriers, and even burnt them as a deterrent. The dumpsters had the added benefit of easy mobility and could be used as moving shields against projectiles such as tear-gas canisters and rubber bullets. When these bins and dumpsters became fewer in number due to their destruction and removal as the months of protests continued, businesses put out their rubbish in black garbage bags tied to signposts 


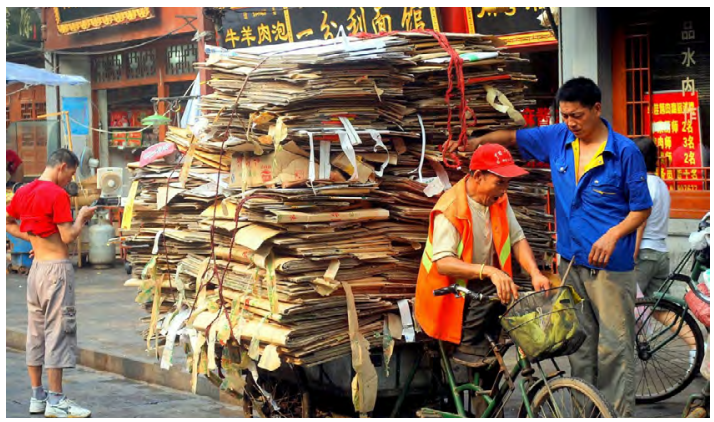

along the street or in piles on the sidewalks and in back alleys. Protesters often shifted these bags on to the road and burned them to serve as blockades when dumpsters were not available.

The waste generated by a city of 7.5 million residents was thus used as a resource in the protests. In turn, the amount of waste generated by the tactical measures of both police and protesters, and simply by crowds of people, added to this rubbish and took on new political significance. Its prolific visibility was an undeniable representation of political, economic, and social crisis in a city where the sight of the elderly poor collecting and neatly sorting cardboard had become so commonplace as to render waste 'invisible' in public space. The international media that reported on the protests sometimes mentioned how careful the protesters were to clean up the streets but were generally uninterested in reporting the details of the tedious clean-up process that followed each clash with police. Each morning, bands of contracted street sweepers and local residents cleaned up the litter-filled landscape, joined by demonstrators eager to show solidarity with people in the community. In some instances, the elderly poor also participated by salvaging what they could find in the aftermath, but most of what was left behind had little or no value.

The new National Security Law may have put a stop to the protests, but the problem of waste - and poverty remains. According to the Hong Kong Environmental Protection Department, as of 2020, the government has already closed thirteen landfill sites, which collectively occupy 300 hectares, due 
to lack of capacity; only three in the New Territories are in active use, despite also operating at capacity.

Waste management has always been a challenge for Hong Kong, which covers 1,106 square kilometres, even before the protests of 2019 and COVID-19 in 2020 disrupted tourism. The Hong Kong service industry is dependent on tourism and, according to the government Tourism Commission, total visitor numbers reached a high of 65.15 million in 2018. In 2020 the city faced multiple related crises: an environmental catastrophe due to mounting levels of rubbish, the COVID-19 pandemic and uncertainty over its future under the new National Security Law. (See Forum, 'Hong Kong's National Security Law', pp.59-64).

The convergence of crises has exacerbated existing social inequities. The downturn in tourism has severely affected the working poor, who are heavily concentrated in the restaurant, catering and accommodation sectors. The elderly working poor continue to struggle to eke out a livelihood in a time of social and economic disruption, and amid a public health emergency that has presented them with the additional challenges of maintaining social distance in crowded quarters, ensuring adequate sanitisation measures and accessing cleaning products and facemasks. The increasingly financialised global economy, with its attendant wealth inequalities, has compounded labour precarity for the working classes in Hong Kong as elsewhere.

Asian societies are facing a 'silver tsunami', with Hong Kong seniors having the longest life expectancy in the world. These elderly people sorting through society's waste are survivors of some of the most dramatic events of the twentieth century, including war, revolution, and the end of British colonisation. Managing waste has long been a livelihood for the poor, whether they are employed to carry it away from public view or they sift through it to reclaim whatever value remains in its use or exchange. The elderly working poor have learned to be resilient in the midst of crises and have found a means for survival among society's discards. But that is not a solution to poverty alleviation and waste reduction. 
This text is taken from China Story Yearbook: Crisis, edited by Jane Golley and Linda Jaivin with Sharon Strange, published 2021 by ANU Press, The Australian National University, Canberra, Australia.

doi.org/10.22459/CSY.2021.02B 